\title{
SoundScape Park \\ Methods
}

\section{Researcher:}

Ebru Özer, ASLA

Associate Professor, Landscape Architecture + Environmental and Urban Design

Florida International University

\section{Research Assistant:}

Skyler Stanford

MLA Candidate

Florida International University

\section{Firm Liaisons:}

Lydia Franken

Public Relations

West 8 New York

Daniel Vasini

Studio Director

West 8 New York

This case study was produced in 2016 in partnership with the researcher, research assistant, and the design firm as part of the Landscape Architecture Foundation's Landscape Performance Series.

To cite:

Özer, Ebru and Skyler Stanford. "SoundScape Park." Landscape Performance Series.

Landscape Architecture Foundation, 2016. https://doi.org/10.31353/cs1181

The full case study can be found at:

https://landscapeperformance.org/case-study-briefs/soundscape-park 
- Landscape Performance Benefits:

\section{Environmental Benefits}

- Environmental Benefit 1- Prevents approximately 1.2 million gallons of stormwater from entering Miami Beach's stormwater system annually, primarily due to a $202 \%$ increase in pervious surface area when compared to previous site conditions.

- Calculations

- Area pre-development: $130,000 \mathrm{sf}$

○ Pervious area: $23,493 \mathrm{sf}$

- Impervious area: $106,507 \mathrm{sf}$

- Area post-development: 130,000 sf

○ Pervious area: $70,876 \mathrm{sf}$

- Impervious area: 59,124 sf

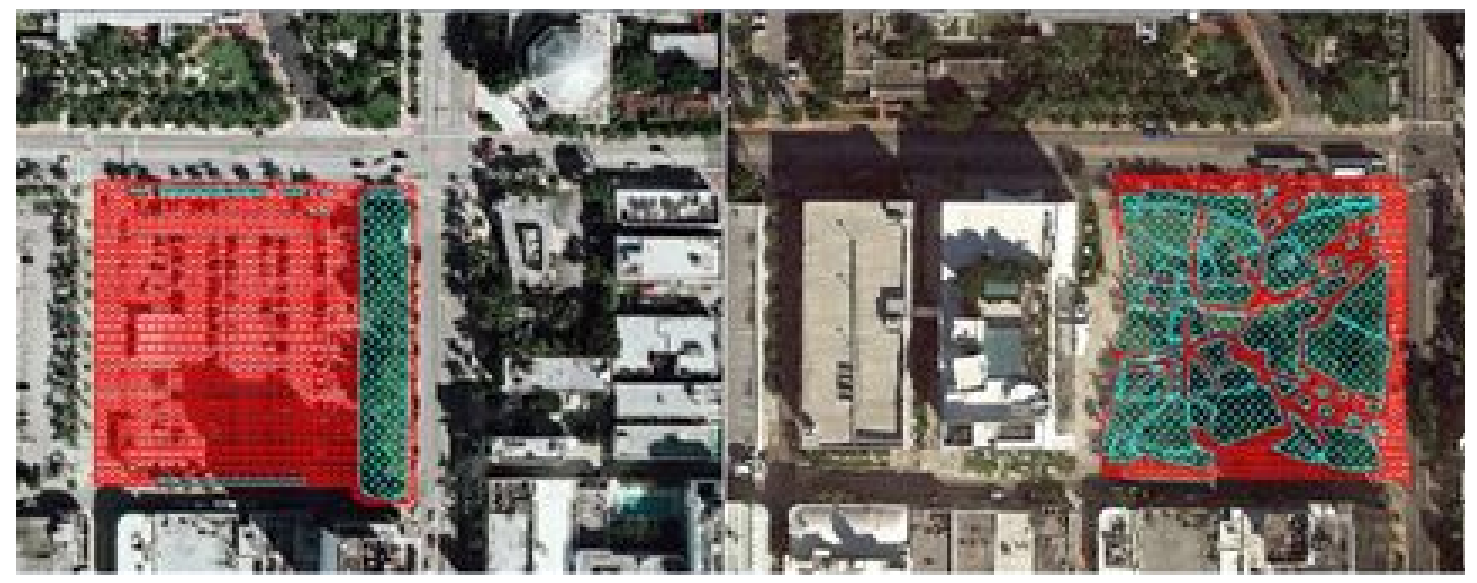

Figure 1. Comparison of pervious (blue) and impervious (red) surfaces between pre-development (left) and post-development (right) conditions.

- The total amount of stormwater was calculated by utilizing the Rational Equation Method $(\mathrm{Q}=\mathrm{CiA})$ which equates peak discharge (runoff) of a drainage field (Soundscape Park) during a specific rain event. The equation typically is used to measure rain events that are short in duration. In order to scale the equation such that it fit the needs of the case study, $i$ was modified to represent the number most indicative of the total rainfall Miami Beach may get for the duration of any hour of any day throughout the year. The city of Miami Beach averages 61.9 inches of rain per year.

\section{$(61.9$ inches/year $) /(365$ days/year $) /(24$ hours/day $)=0.0071$ inches $/$ hour $=\mathbf{i}$}

- The acreage of impervious and pervious surfaces of the park both pre- and post-development were input into the equation as $A$. The 
Runoff Coefficient, $C$, is unique to the ground conditions of the watershed. In the equation, 0.05 was utilized for the pervious areas while 0.7 was utilized for the impervious areas.

\begin{tabular}{|l|l|}
\hline Groundcover & Runoff Coefficient, $c$ \\
\hline Lawns & $0.05-0.35$ \\
\hline Forest & $0.05-0.25$ \\
\hline Cultivated Land & $0.08-0.41$ \\
\hline Meadow & $0.1-0.5$ \\
\hline Parks, cemeteries & $0.1-0.25$ \\
\hline Unimproved areas & $0.1-0.3$ \\
\hline Pasture & $0.12-0.62$ \\
\hline Residential areas & $0.3-0.75$ \\
\hline Business areas & $0.5-0.95$ \\
\hline Industrial areas & $0.5-0.9$ \\
\hline Asphalt streets & $0.7-0.95$ \\
\hline Brick streets & $0.7-0.85$ \\
\hline Roofs & $0.75-0.95$ \\
\hline Concrete streets & $0.7-0.95$ \\
\hline
\end{tabular}

- To equate the total volume of runoff throughout the year, $Q$, units being cubic feet per second, was scaled to represent yearly runoff in total cubic feet then converted to total gallons of runoff per year. The total difference between pre-development conditions and postdevelopment conditions was then calculated. 


\begin{tabular}{|c|c|c|c|c|r|r|r|}
\hline \multicolumn{9}{|c|}{ Stormwater Runoff Pre-Development } \\
\hline Description & Area (in s.f.) & i (inches/hour) & Area (acres) & C (co-efficient) & $\begin{array}{c}\text { Q (Q=CiA) in } \\
\text { c.f.s. }\end{array}$ & $\begin{array}{c}\text { Total Volume } \\
\left(=\mathbf{Q}^{*} \text { Time) in c.f. }\right.\end{array}$ & $\begin{array}{c}\text { Total Volume in } \\
\text { Gal. }\end{array}$ \\
\hline pervious & $23,493.00$ & 0.0071 & 0.5393 & 0.05 & 0.00019145 & $6,037.61$ & $45,161.36$ \\
\hline impervious & $106,507.00$ & 0.0071 & 2.4451 & 0.70 & 0.01215215 & $383,230.11$ & $2,866,561.21$ \\
\hline Total & $130,000.00$ & & & & & $389,267.72$ & $2,911,722.56$ \\
\hline
\end{tabular}

\begin{tabular}{|c|c|c|c|c|r|r|r|}
\hline \multicolumn{9}{|c|}{ Stormwater Runoff Post-Development } \\
\hline Description & Area (in s.f.) & i (inches/hour) & Area (acres) & C (co-efficient) & $\begin{array}{c}\text { Q (Q= CiA) in } \\
\text { c.f.s. }\end{array}$ & $\begin{array}{c}\text { Total Volume } \\
\left(=\mathbf{Q}^{*} \text { Time) in c.f. }\right.\end{array}$ & $\begin{array}{c}\text { Total Volume in } \\
\text { Gal. }\end{array}$ \\
\hline pervious & $70,876.00$ & 0.0071 & 1.6271 & 0.05 & 0.00057762 & $18,215.84$ & $136,254.48$ \\
\hline impervious & $59,124.00$ & 0.0071 & 1.3573 & 0.70 & 0.00674578 & $212,734.95$ & $1,591,257.42$ \\
\hline Total & $130,000.00$ & & & & & $230,950.79$ & $1,727,511.91$ \\
\hline \multicolumn{7}{|c|}{} \\
\cline { 2 - 8 } & Total Difference & $1,184,210.66$ \\
\hline
\end{tabular}

Table 2. Stormwater Runoff Calculations, pre- and post-development SoundScape Park.

- Limitations

- Precision: There may be small errors caused by manual tracing of aerial imagery.

- Image quality: While the quality of the images is very high, there are portions that are pixelated and/or covered in shadow from adjacent buildings. We estimated the areas to the best of our capabilities. Since the image quality was identical for both pre- and post-intervention aerials, it could be argued that human error was identical for both and thus negligible in the final calculations.

- The equation $Q=C i A$, when scaled out to represent the total hourly rainfall during any given hour throughout the year, doesn't take into account large rainfall events, where total discharge may be greater than average.

- Sources

- http://www.lmnoeng.com/Hydrology/rational.php

- Environmental Benefit 2 - Sequesters approximately 9.5 tons of atmospheric carbon in 355 newly-planted trees.

- Calculations

- To determine the amount of $\mathrm{CO}_{2}$ captured by the trees, we utilized the National Tree Benefit Calculator (TREE). The tree value calculator is based upon the iTree Streets software program developed by the USDA Forest Service for approximating street tree benefits. The tree value calculator required us to identify the trunk diameter at breast height $(\mathrm{DBH})$ for the species on site. Once the $\mathrm{DBH}$ was measured, that value was input into the National 
Tree Benefit Calculator where it output stormwater and $\mathrm{CO}_{2}$ values.

\begin{tabular}{|c|c|c|c|c|c|c|c|c|c|c|c|c|c|c|}
\hline & $\begin{array}{l}\text { Veitchia } \\
s p \text {.(SS) }\end{array}$ & $\begin{array}{l}\text { Veitchia } \\
s p .(S D)\end{array}$ & $\begin{array}{l}\text { Veitchia } \\
\text { sp. (ST) }\end{array}$ & $\begin{array}{l}\text { Veitchia } \\
\text { sp.(TS) }\end{array}$ & $\begin{array}{l}\text { Veitchia } \\
s p .(T D)\end{array}$ & $\begin{array}{l}\text { Veitchia } \\
s p .(T T)\end{array}$ & $\begin{array}{l}\text { Veitchia } \\
\text { sp. (MS) }\end{array}$ & $\begin{array}{l}\text { Veitchia } \\
\text { sp. (MD) }\end{array}$ & $\begin{array}{l}\text { Veitchia } \\
s p .(M T)\end{array}$ & \begin{tabular}{|c|} 
Dictyospe \\
$r m a$ \\
$s p .(H S)$ \\
\end{tabular} & \begin{tabular}{|c|} 
Dictyospe \\
$r m a$ \\
$s p .(H D)$
\end{tabular} & $\begin{array}{c}\text { Dictyospe } \\
\text { rma sp. } \\
(H T)\end{array}$ & \begin{tabular}{|c|} 
Quercus \\
virginiana \\
(LO)
\end{tabular} & $\begin{array}{l}\text { Delonix } \\
\text { regia (FL) }\end{array}$ \\
\hline ZONE A & 3 & & & 17 & 5 & 2 & 14 & 3 & 3 & 30 & & 2 & & \\
\hline ZONE B & 1 & & & 10 & 2 & 4 & 10 & 4 & 4 & 10 & 2 & & & 1 \\
\hline ZONE C & 1 & 1 & 1 & 18 & 5 & 8 & 21 & 5 & 3 & 4 & & & 1 & \\
\hline ZONE D & 3 & 2 & & 11 & 8 & & 10 & 6 & 2 & 2 & 1 & & 3 & 2 \\
\hline ZONE E & & & & 19 & 6 & 6 & 25 & 6 & 3 & 2 & 1 & & 1 & 1 \\
\hline ZONE F & & & & 28 & 3 & 3 & 3 & & & 3 & & & & \\
\hline \multirow[t]{2}{*}{ totals \#s } & 8 & 3 & 1 & 103 & 29 & 23 & 83 & 24 & 15 & 51 & 4 & 2 & 5 & 4 \\
\hline & & & & & & & & & & & & & total & 355 \\
\hline specs & $\begin{array}{c}40-45^{\prime} \text { o.a. } \\
\text { height, } \\
\text { single }\end{array}$ & $\begin{array}{c}40-45^{\prime} \text { o.a. } \\
\text { height, } \\
\text { double }\end{array}$ & $\begin{array}{c}40-45^{\prime} \text { o.a. } \\
\text { height, } \\
\text { triple }\end{array}$ & $\begin{array}{l}>25 \text { ' o.a. } \\
\text { height, } \\
\text { single }\end{array}$ & $\begin{array}{l}>25 \text { ' o.a. } \\
\text { height, } \\
\text { double }\end{array}$ & $\begin{array}{l}>25 \text { ' o.a. } \\
\text { height, } \\
\text { triple }\end{array}$ & $\begin{array}{c}16-25^{\prime} \text { o.a. } \\
\text { height, } \\
\text { single }\end{array}$ & $\begin{array}{c}16-25 \text { ' o.a. } \\
\text { height, } \\
\text { double }\end{array}$ & $\begin{array}{c}16-25^{\prime} \text { o.a. } \\
\text { height, } \\
\text { triple }\end{array}$ & $\begin{array}{c}12-15^{\prime} \text { o.a. } \\
\text { height, } \\
\text { single }\end{array}$ & $\begin{array}{c}12-15 \text { ' o.a. } \\
\text { height, } \\
\text { double }\end{array}$ & $\begin{array}{c}12-15^{\prime} \text { o.a. } \\
\text { height, } \\
\text { single }\end{array}$ & \begin{tabular}{|c|}
$35^{\prime}$ o.a., $2-$ \\
5 trunks \\
$(8-12 "$ \\
caliper)
\end{tabular} & $\begin{array}{c}25 \text { ' o.a., } \\
12 " \\
\text { caliper }\end{array}$ \\
\hline \begin{tabular}{|c|}
$\begin{array}{c}\text { Stormwater } \\
\text { intercepted/tree (in } \\
\text { gal.) }\end{array}$ \\
\end{tabular} & 289 & 362 & 430 & 249 & 318 & 376 & 198 & 274 & 318 & 198 & 274 & 318 & 825 & 773 \\
\hline $\begin{array}{c}\text { CO2 sequestered/tree } \\
\text { (in pounds) }\end{array}$ & 59 & 67 & 67 & 52 & 62 & 67 & 41 & 57 & 62 & 41 & 57 & 62 & 174 & 162 \\
\hline \multirow[t]{2}{*}{ Total gal. per year } & 2312 & 1086 & 430 & 25647 & 9222 & 8648 & 16434 & 6576 & 4770 & 10098 & 1096 & 636 & 4125 & 3092 \\
\hline & & & & & & & & & & & & & total (gal.) & 94172 \\
\hline \multirow[t]{2}{*}{ Total lbs. per year } & 472 & 201 & 67 & 5356 & 1798 & 1541 & 3403 & 1368 & 930 & 2091 & 228 & 124 & 870 & 648 \\
\hline & & & & & & & & & & & & & total (Ibs) & 19097 \\
\hline
\end{tabular}

Table 3. Calculations of CO2 sequestration (in lbs.)

- Limitations

- The online calculator does not assess non-tree vegetation such as grass and small shrubs which account for a sizeable portion of the site.

- The online calculator does not list all the tree species that were used in the project. For instance, the Live Oak (Quercus virginiana) was not available on the online calculator and instead was replaced as an input by the placeholder or generic "Large Broadleaf Deciduous Tree". It is unclear how much this may or may not skew the results.

- Sources

- http://www.treebenefits.com/calculator/

- Environmental Benefit 3 - Reduces air temperatures in the park by an average of $4.7^{\circ} \mathrm{F}$ when compared to the adjacent sidewalk, primarily due to a $270 \%$ increase in canopy coverage.

- Calculations

- Total canopy cover was calculated by tracing the canopy cover of aerial imagery of Soundscape Park in its pre-development state as well as in its post-development state. The respective areas of both tree canopies were then compared. 


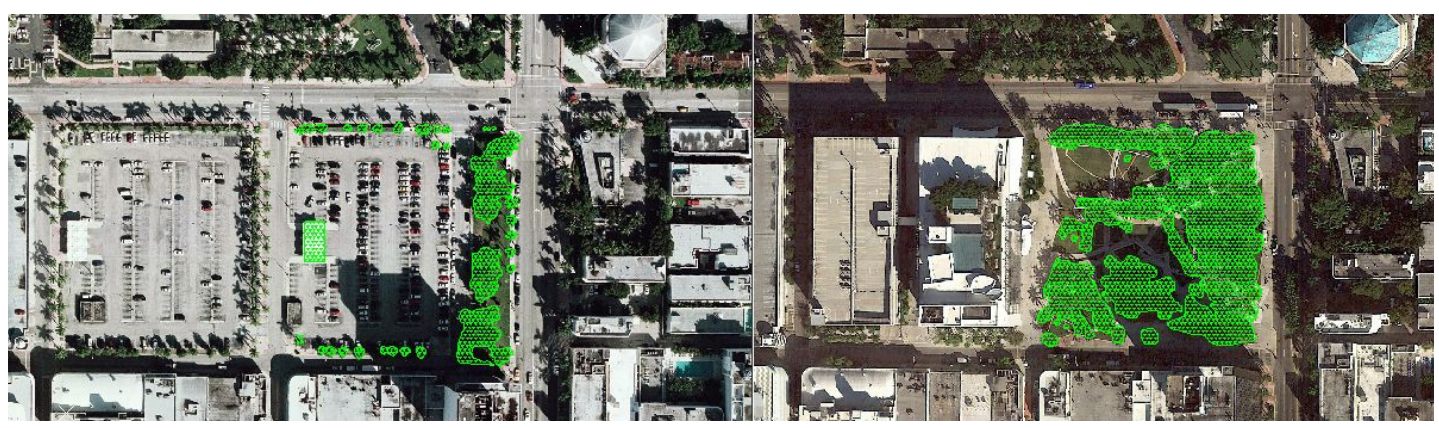

Figure 2. Canopy cover in pre- and post-development conditions (left and right respectively).

- Temperature measurements were calculated through direct measurement of on-site air temperatures taken hourly over an 8 hour period on two separate days, May 7, 2016 and May 12, 2016.

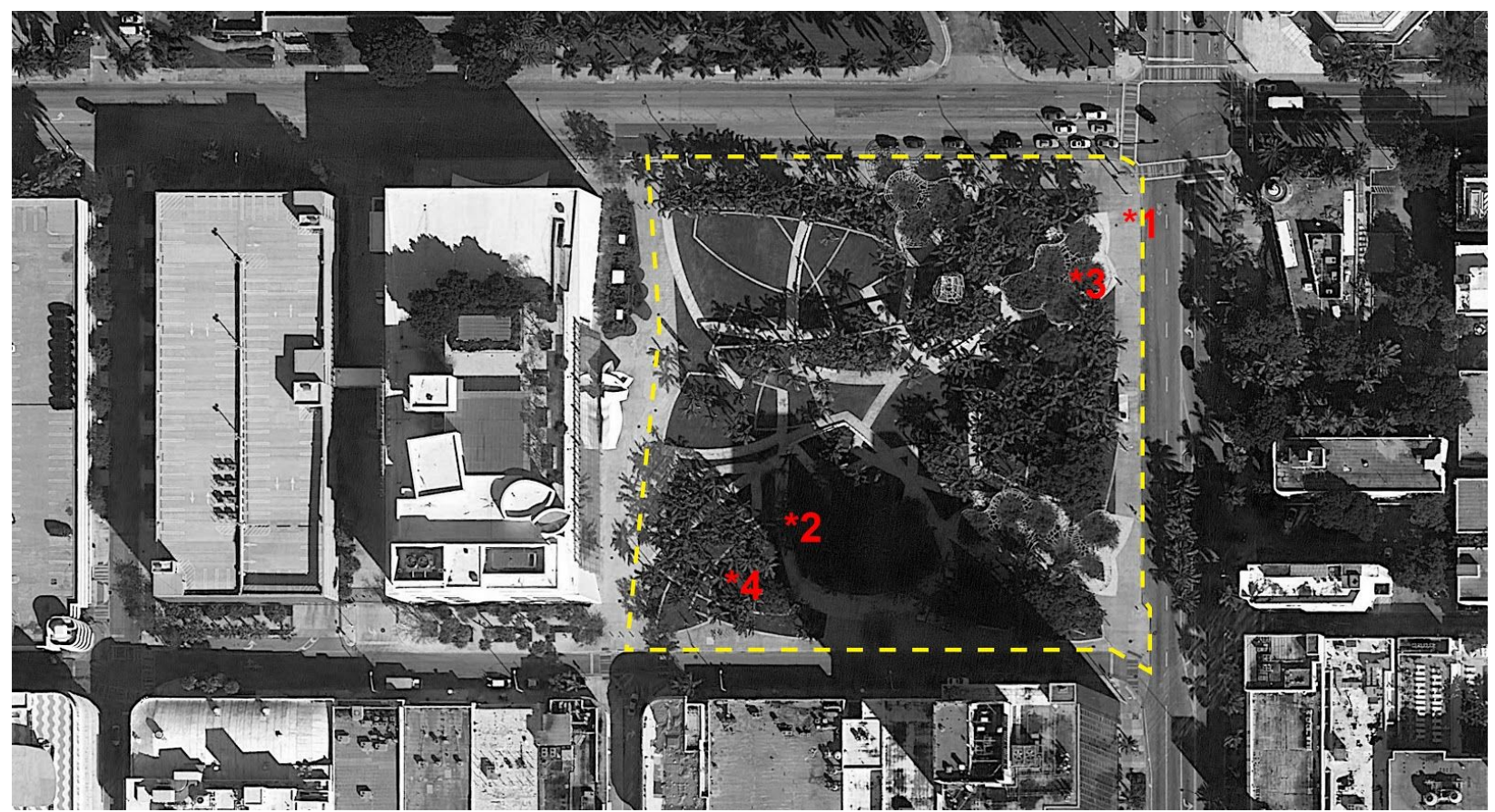

Figure 3. Temperature Measurement locations. 


\begin{tabular}{|c|c|c|c|c|c|c|c|c|}
\hline \multirow[b]{2}{*}{ Time of day } & \multirow[b]{2}{*}{$\begin{array}{l}\text { Weather } \\
\text { condition }\end{array}$} & \multicolumn{7}{|c|}{$\begin{array}{c}\text { Saturday } 5 / 7 / 2016 \\
\text { Temperatures read }\left({ }^{\circ} \mathrm{F}\right) \& \text { Temperature differences }\end{array}$} \\
\hline & & $\begin{array}{c}\text { NorthEast } \\
\text { Sidewalk }(\star 1) \\
\text { above concrete } \\
\text { sidewalk }\end{array}$ & $\begin{array}{c}\text { SouthWest } \\
\text { Seatwall }(\star 2) \\
\text { above concrete bench } \\
\text { under a palm tree }\end{array}$ & $\begin{array}{c}\text { Temperature } \\
\text { differences } \\
\text { between } \star 1 \& \star 2\end{array}$ & $\begin{array}{c}\text { NorthEast } \\
\text { Entrywalk }(\star 3) \\
\text { above concrete } \\
\text { walkway under } \\
\text { vinecovered structure }\end{array}$ & $\begin{array}{c}\text { Temperature } \\
\text { differences } \\
\text { between } \star 1 \& \star 3\end{array}$ & $\begin{array}{c}\text { SouthWest } \\
\text { Grassland }(\star 4) \\
\text { above grass } \\
\text { under a palm tree }\end{array}$ & $\begin{array}{c}\text { Temperature } \\
\text { differences } \\
\text { between } \star 1 \& \star 4\end{array}$ \\
\hline 9:00 AM & Sunny & 75.4 & 75.9 & 0.5 & 69.6 & -5.8 & 71.6 & -3.8 \\
\hline $10: 00 \mathrm{AM}$ & Sunny & 79.2 & 74.1 & -5.1 & 71.2 & -8 & 73.6 & -5.6 \\
\hline $11: 00 \mathrm{AM}$ & Sunny & 78.8 & 77.2 & -1.6 & 74.8 & -4 & 75.6 & -3.2 \\
\hline 12:00 PM & Sunny & 83.1 & 81.1 & -2 & 77.4 & -5.7 & 77.4 & -5.7 \\
\hline 1:00 PM & Sunny & 89.1 & 80.6 & -8.5 & 78.1 & -11 & 81.3 & -7.8 \\
\hline 2:00 PM & Sunny & 85.6 & 81.5 & -4.1 & 80.1 & -5.5 & 79 & -6.6 \\
\hline 3:00 PM & Sunny & 84.9 & 82.9 & -2 & 82.5 & -2.4 & 80.2 & -4.7 \\
\hline 4:00 PM & Sunny & 84.2 & 85.6 & 1.4 & 82.8 & -1.4 & 79 & -5.2 \\
\hline 5:00 PM & Sunny & 81.9 & 82.8 & 0.9 & 80.6 & -1.3 & 77.2 & -4.7 \\
\hline & Averages & 82.5 & 80.2 & -2.3 & 77.5 & -5.0 & 77.2 & -5.3 \\
\hline
\end{tabular}

\begin{tabular}{|c|c|c|c|c|c|c|c|c|}
\hline \multirow[b]{2}{*}{ Time of day } & \multirow[b]{2}{*}{$\begin{array}{l}\text { Weather } \\
\text { condition }\end{array}$} & \multicolumn{7}{|c|}{$\begin{array}{l}\text { Friday } 5 / 12 / 2016 \\
\text { Temperatures read }\left({ }^{\circ} \mathrm{F}\right) \& \text { Temperature differences }\end{array}$} \\
\hline & & $\begin{array}{c}\text { NorthEast } \\
\text { Sidewalk }(\star 1) \\
\text { above concrete } \\
\text { sidewalk }\end{array}$ & $\begin{array}{c}\text { SouthWest } \\
\text { Seatwall }(\star 2) \\
\text { above concrete bench } \\
\text { under a palm tree }\end{array}$ & $\begin{array}{c}\text { Temperature } \\
\text { differences } \\
\text { between } \star 1 \& \star 2\end{array}$ & $\begin{array}{c}\text { NorthEast } \\
\text { Entrywalk }(\star 3) \\
\text { above concrete } \\
\text { walkway under } \\
\text { vinecovered structure }\end{array}$ & $\begin{array}{c}\text { Temperature } \\
\text { differences } \\
\text { between } \star 1 \& \star 3\end{array}$ & $\begin{array}{c}\text { SouthWest } \\
\text { Grassland }(\star 4) \\
\text { above grass } \\
\text { under a palm tree }\end{array}$ & $\begin{array}{c}\text { Temperature } \\
\text { differences } \\
\text { between } \star 1 \& \star 4\end{array}$ \\
\hline 9:00 AM & Mostly sunny & 83.1 & 80.8 & -2.3 & 81.3 & $\begin{array}{l}-1.8 \\
\end{array}$ & 79.9 & -3.2 \\
\hline $10: 00 \mathrm{AM}$ & Mostly sunny & 88.2 & 82.4 & -5.8 & 82.2 & -6 & 83.1 & -5.1 \\
\hline $11: 00 \mathrm{AM}$ & Partly sunny & 88.5 & 84.4 & -4.1 & 82.4 & -6.1 & 83.3 & -5.2 \\
\hline 12:00 PM & Partly sunny & 90.1 & 84 & -6.1 & 83.1 & -7 & 83.1 & -7 \\
\hline 1:00 PM & Cloudy & 89.8 & 86.5 & -3.3 & 83.7 & -6.1 & 83.1 & -6.7 \\
\hline 2:00 PM & Cloudy & 91.9 & 88.3 & -3.6 & 84.6 & -7.3 & 84.2 & -7.7 \\
\hline 3:00 PM & Cloudy & 91.6 & 87.8 & -3.8 & 85.8 & -5.8 & 83.9 & -7.7 \\
\hline 4:00 PM & louds and su & 90.9 & 87.8 & -3.1 & 86.4 & -4.5 & 82.9 & -8 \\
\hline 5:00 PM & Cloudy & 87.4 & 86 & -1.4 & 83.5 & -3.9 & 82 & -5.4 \\
\hline & Averages & 89.1 & 85.3 & -3.7 & 83.7 & -5.4 & 82.8 & -6.2 \\
\hline
\end{tabular}

Table 4. Temperature Measurements Saturday, May 7, 2016 + Friday, May 12, 2016

- Average of 6 temperature differences above $=4.65^{\circ} \mathrm{F}$

- Limitations

- Precision: There may be small errors caused by manual tracing of aerial imagery.

- Image quality: While the quality of the images is very high, there are portions that are pixelated and/or covered in shadow from adjacent buildings. We estimated the areas to the best of our capabilities. Since the image quality was identical for both pre- and post-intervention aerials, it could be argued that human error was identical for both and thus negligible in the final calculations.

\section{Social Benefits}

- Social Benefit 1 - Attracts approximately 870 users on a typical May weekday and 1,000 people over an 8-hour period on a typical May weekend day.

- Calculations 

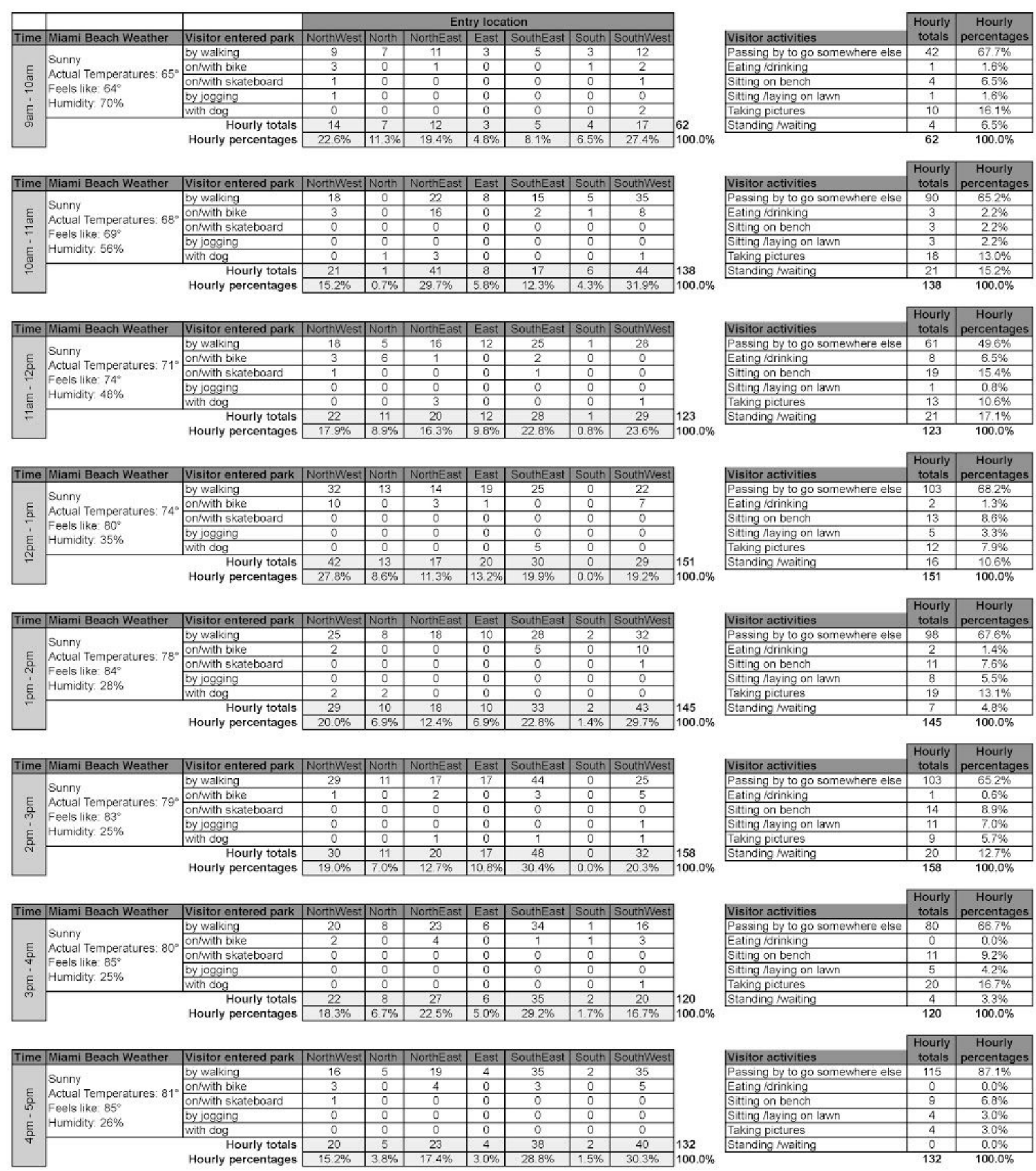

Table 5. Total Visitor Count was 1029 for Saturday May 7, 2016 from 9:00 am-5:00 pm. 

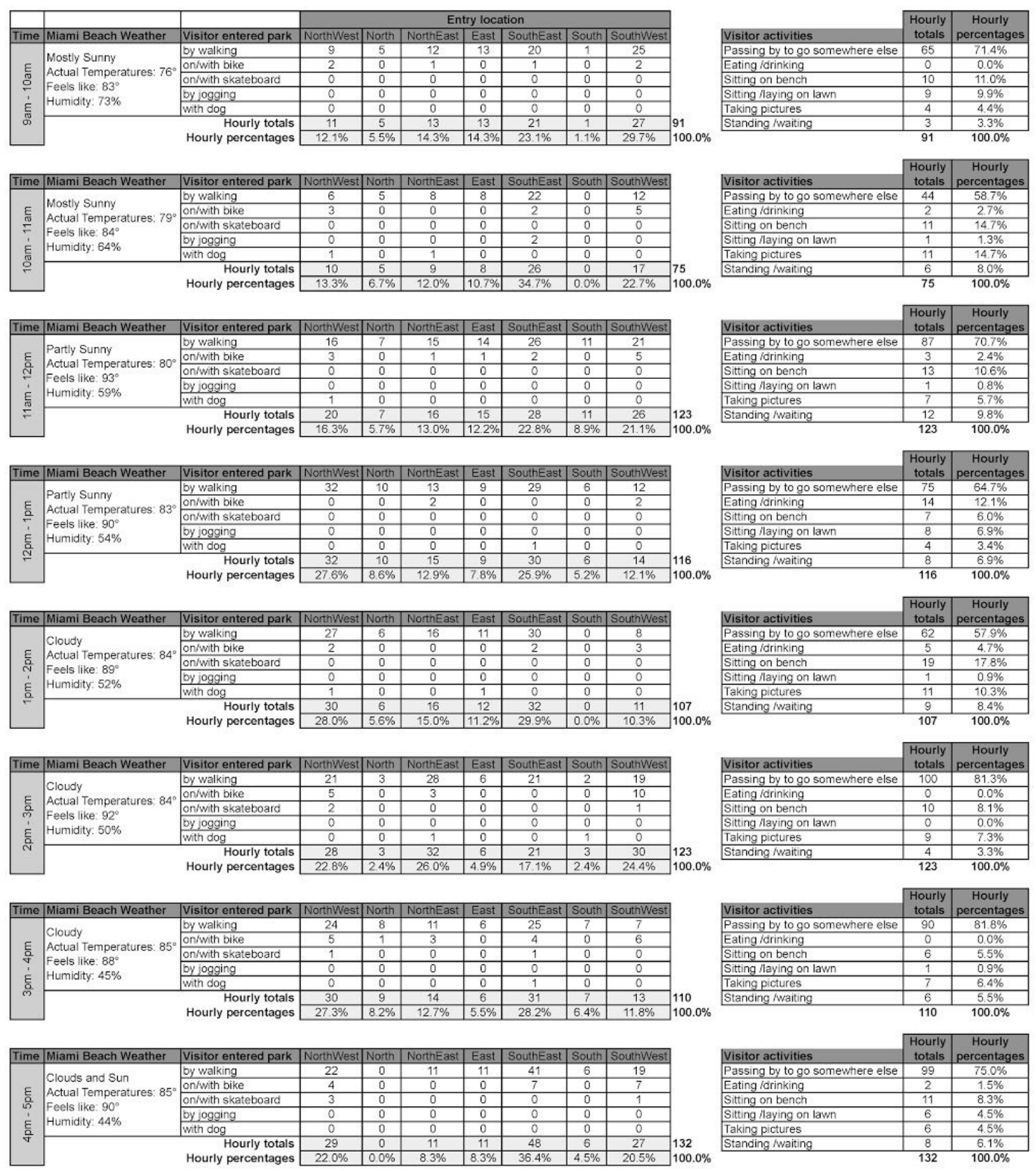

Table 6. Total Visitor Count was 877 on Friday May 12, 2016 from 9:00 am-5:00 pm.

- Limitations

- The research team manually counted visitors from two particular vantage points at the park. They also distinguished between those who were simply passing by to go somewhere else, those who were utilizing the facilities on-site (i.e. waiting at bus stop), and those who came to the park to enjoy the various amenities offered. 
- Due to the counting activity taking place during a specific weekend and weekday in May, the numbers gathered are not necessarily reflective of the amount of visitors that may utilize the park at other times.

- Evening foot traffic and events taking place at night, such as movie screenings or symphony performances, were not accounted for in these figures.

- Social Benefit 2 - Positively influences the satisfaction with quality of life in Miami Beach according to $82 \%$ of 84 survey respondents.

- Calculations

- To measure Social Benefits 2-6 the research team created a survey that was carried out on-site. A total of 84 respondents participated in the survey.

Spending time in this park influences my satisfaction with quality of life in this city.

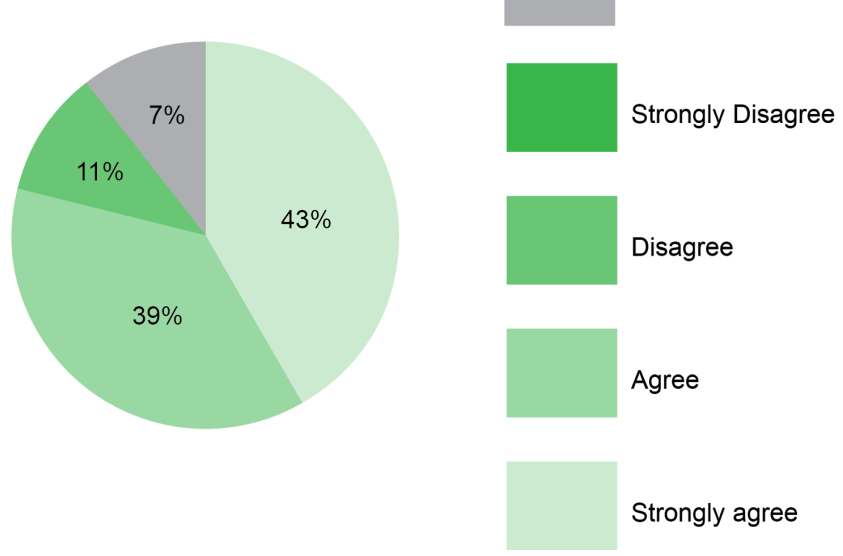

Table 7. $82 \%$ of survey participants agreed that spending time in SoundScape Park positively influences their satisfaction with quality of life in the City of Miami Beach.

- Social Benefit 3 - Provides stress relief according to $60 \%$ of 84 survey respondents.

Spending time in this park helps me to cope with the demands of work, family, and other stressful situations.

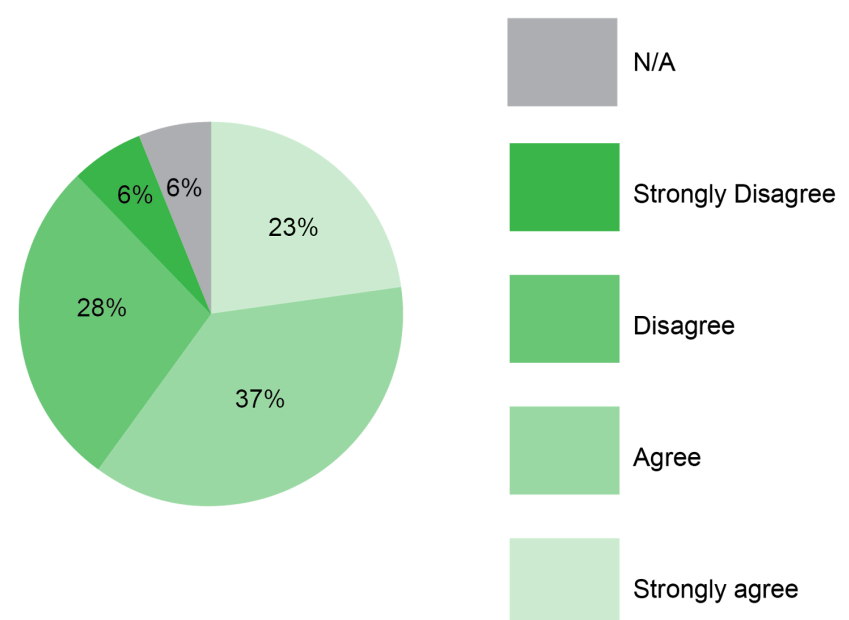


Table $8.60 \%$ of survey participants agreed that spending time in SoundScape Park helps them to cope with stress.

- Social Benefit 4 - Increases user exposure to music performances or other cultural events according to $45 \%$ of 84 survey respondents by hosting over 50 events annually.

\section{Has the existence of this park increased your exposure to music performances or other cultural events?}
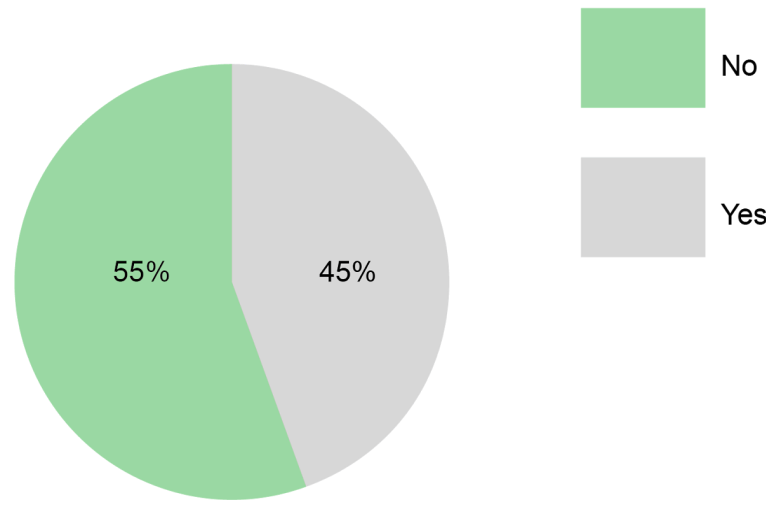

Table 9. 45\% of survey participants said that SoundScape Park increases their exposure to music performances and cultural events.

\section{Economic Benefits}

- Economic Benefit 1 - Contributed to a $60 \%$ increase in the total assessed value of properties within a block of Soundscape Park from 2010 to 2015. This led to a $\$ 1.2$ million (60\%) increase in yearly property tax revenues. During that same period, gross property values for the entirety of the City of Miami Beach increased by only $36 \%$.

- Calculations

- Assessed property value of the surrounding area was obtained from the Miami-Dade Property Appraiser (MDPA) to calculate the change in property value from the year prior to the intervention to present (2010-2015). 


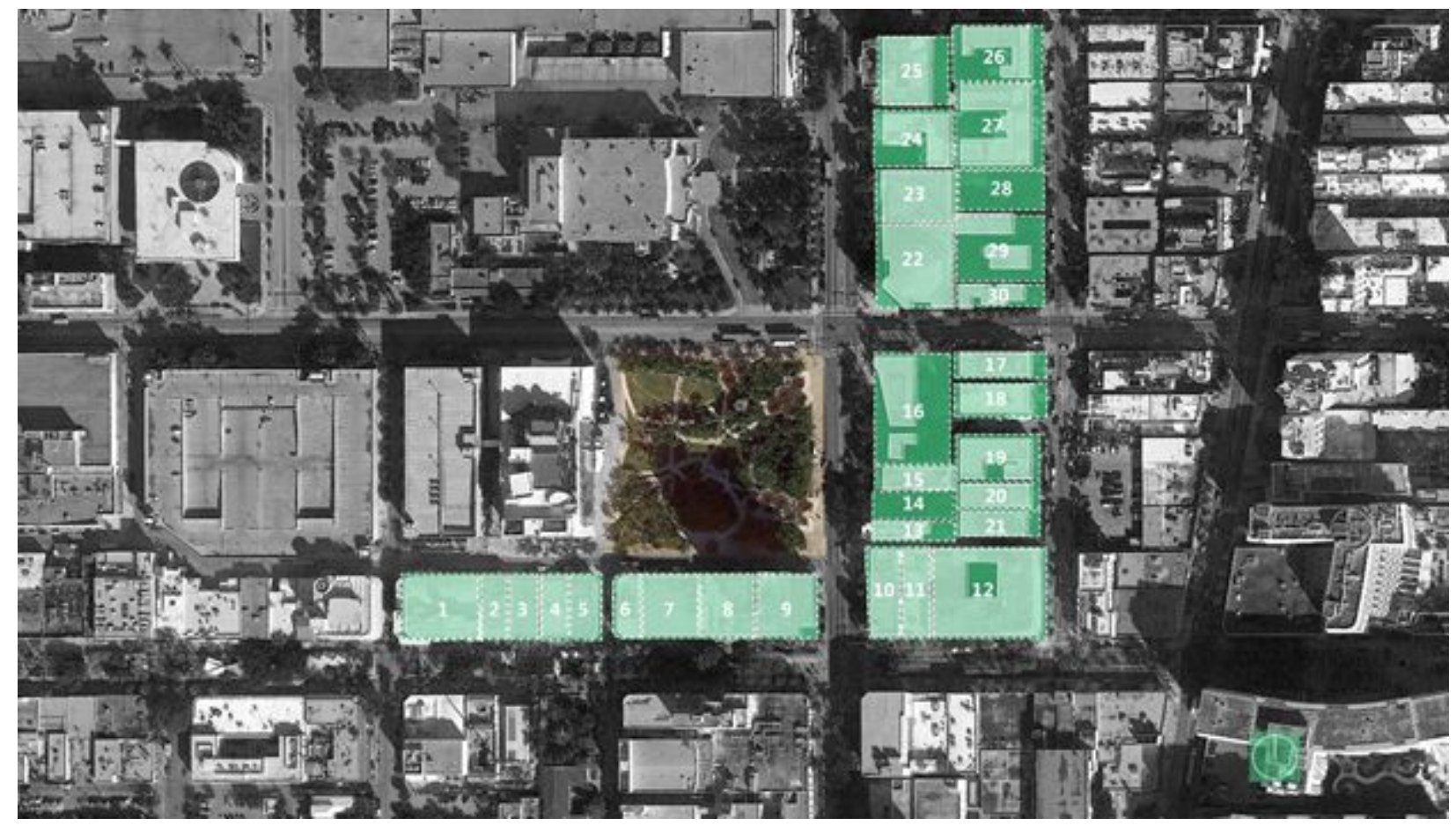

Figure 4. Properties surrounding SoundScape Park marked in green; SoundScape Park in color in center. 


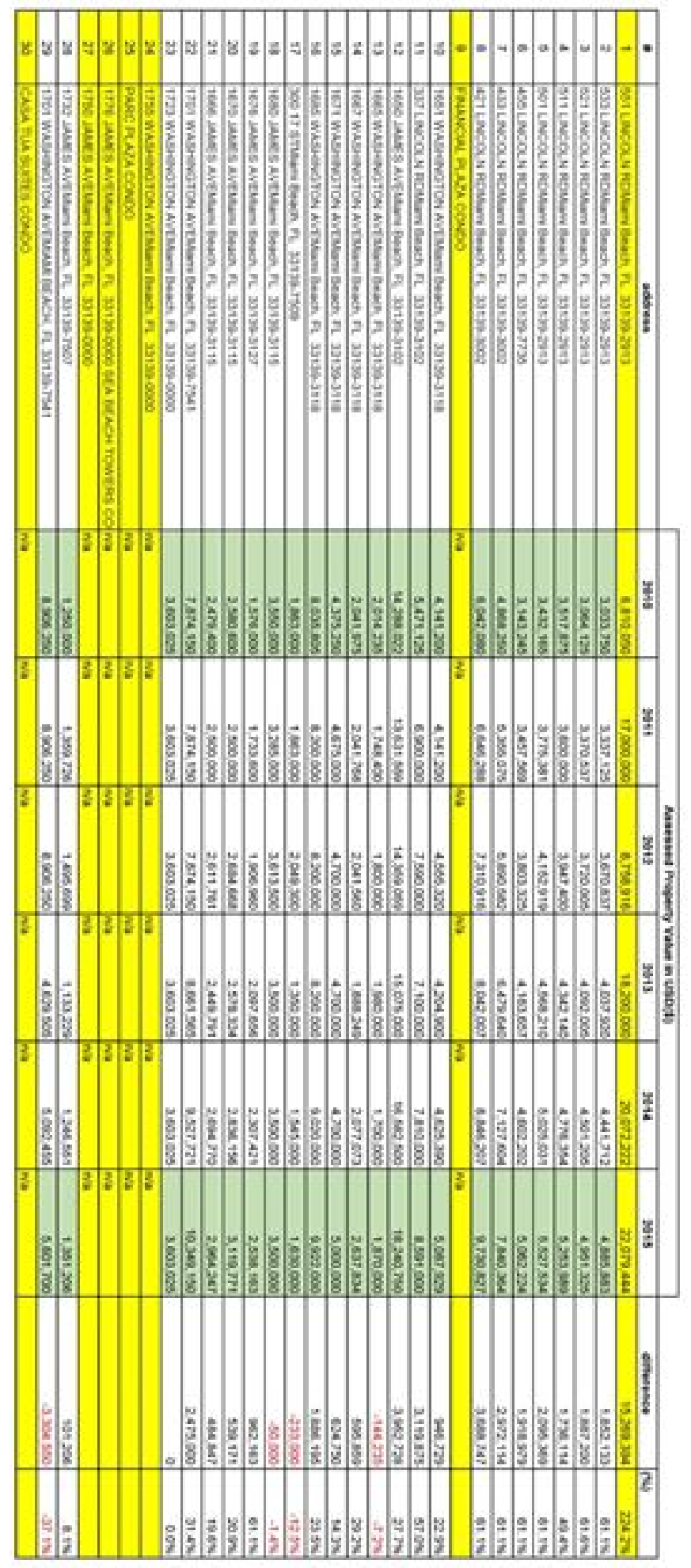

Table 10. Property Values corresponding to location on map in Figure 4. 
- Yellow highlighted properties were omitted for the following reasons:

- Property 1 has undergone significant additions with the implementation of a movie theater complex between 2010 and 2011, a term during which property value increased by $250 \%$. Since this value increase was a direct result of an architectural intervention, this property was excluded from calculation.

- Properties 9, 22-27, and 29-30, were excluded due to being private condo establishments, whose property taxes were not disclosed publicly in the county's Property Report Card feature.

To calculate the increase in tax revenues, we utilized the Miami-Dade Property Report Card (MDPRC) to document each unit's paid property tax per year from 2010-2015. The numbers were placed into Excel for comparison and additional calculation. 


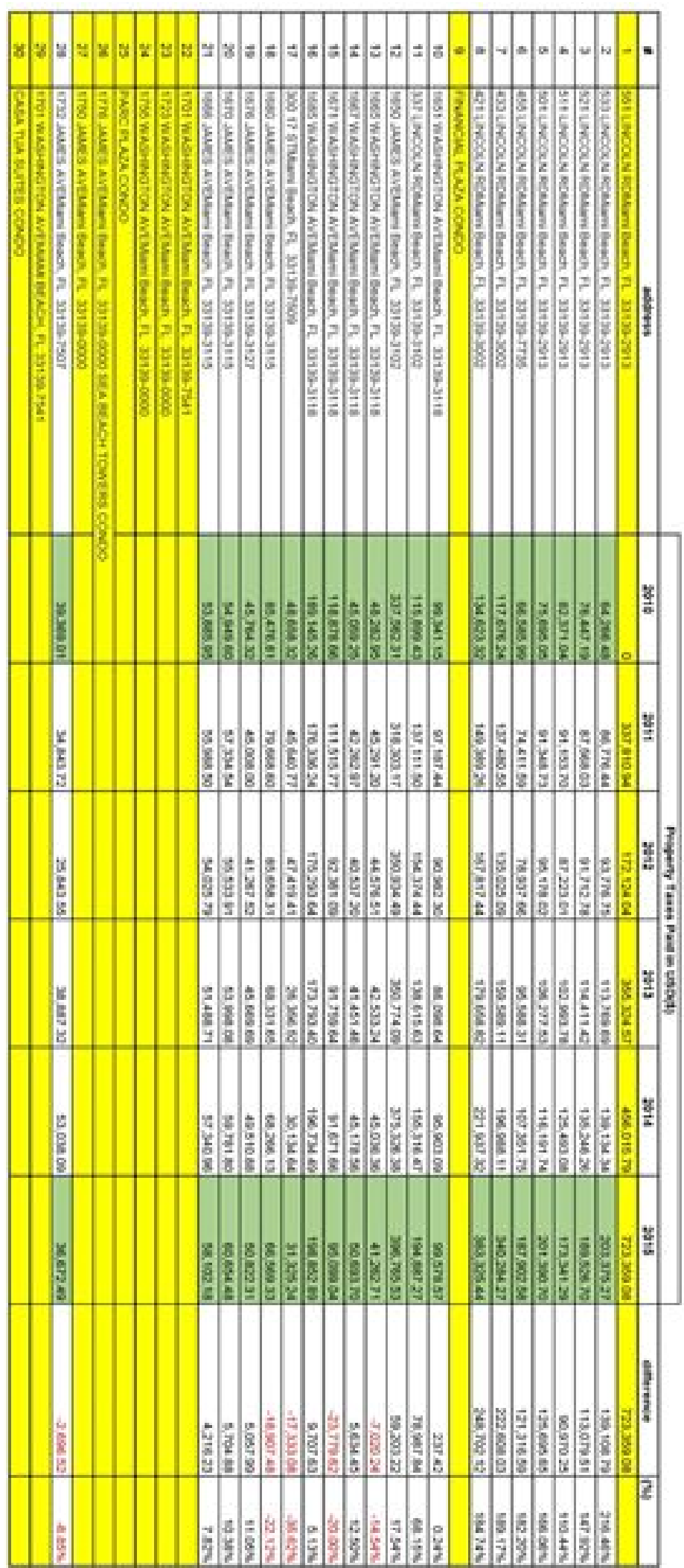

Table 11. Property taxes paid in USD corresponding to location on map in Figure 4. 
- Limitations

- The design of the park was supplementary to the development of the New World Center, a concert hall designed by Frank Gehry, which houses the New World Symphony. Furthermore, significant investment has gone into Lincoln Road - the adjacent pedestrian mall due south of Soundscape Park - during this period of time. It is not entirely possible to separate the impact of the park with that of the New World Center and it is probable that they have both contributed to the significant increases in property values and property tax revenues during the aforementioned period.

- Sources

- http://www.miamidade.gov/pa/property search.asp

- http://www.miamidade.gov/PaPortal/PRC/CreatePRCmain.aspx

- Cost Comparison

- In order to maximize site usage from day one, fully mature, locally-sourced trees were individually tagged for installation in the park. Combined with highly specific soil and irrigation strategies and unique tree anchoring methods, the trees were planted into zones to ensure tree survival and minimize pedestrian impact. A planting plan calling for mature palms greater than $16 \mathrm{ft}$ in height, in some cases greater than $25 \mathrm{ft}$ in height, did incur a greater cost than a plan utilizing palms shorter than $12 \mathrm{ft}$ would have. A modular suspended pavement system was also utilized in the installation of 5 mature live oaks and 4 mature royal poincianas. Rather than opt for the more conservative route of planting smaller, juvenile trees in standard planting soil, the city and firm opted for the route which maximized the potential of the site from day one. An additional cost of $\$ 1,239,350$ for larger trees, structural cells, and improved soil quality was deemed necessary by the city in order for the park to function at an optimum level sooner rather than later.

$\circ$ In order to arrive at the figure for a cost increase of $\$ 1,239,350$ for larger trees, structural cells, and improved soil quality, the following methods for calculation were utilized:

- Prices of trees less than 12' tall were determined based on local nursery sourcing and pricing. These numbers were compared to the cost of trees at requested dimensions and quantities (as per the landscape architect's plans), the numbers of which were also based on prices of equal or similarly-sized trees available at local nursery providers in the Miami-Dade region. If a similarly-sized tree could not be found within the region, the Tree Value calculator was utilized.

- Finally, the determination of the cost of Silva Cells specified in the landscape architect's plans for 5 Live Oaks were determined based on pricing from the Silva Cell provider's website.

- Calculations

- Cost of trees less than or equal to 12'

- Montgomery Palm, Veitchia montgomeryana (via Hopetown 
Farms in Loxahatchee, Florida)

- Singles: $\$ 168$

- Doubles: $\$ 168$

- Triples: $\$ 218$

- Hurricane Palm, Dictyosperma sp. (via Jesse Durko's Nursery in Davie, Florida)

- $\$ 120$

- Live Oak, Quercus virginiana (via Stewart's Tree Service in Brooksville, Florida)

- $\$ 250$

- Royal Poinciana, Delonix regia (via Salazar's Two Sisters Nursery in Homestead, Florida)

- $\$ 120$

- Cost of trees at equal sizes

- Montgomery Palm, Veitchia montgomeryana.

- Requested specs and (quantities) from Landscape Architect's plans:

- 40-45' o.a. Height, single trunk (x8)

- 40-45' o.a. Height, double trunk (x3)

- 40-45' o.a. Height, triple trunk (x1)

- $>25$ ' o.a. Height, single trunk (x103)

- $>25$ ' o.a. Height, double trunk (x29)

- $>25$ ' o.a. Height, triple trunk (x23)

- 16-25' o.a. Height, single trunk (x83)

- 16-25' o.a. Height, double trunk (x24)

- 16-25' o.a. Height, triple trunk (x15)

- Cost of Veitchia is determined by using the nursery's pricing guidelines of:

- $\$ 10 / \mathrm{ft}$. For single trunk varieties

- $\$ 12 / \mathrm{ft}$. For doubles

- $\$ 17 / \mathrm{ft}$. For triples

- Hurricane Palm, Dictyosperma sp.

- Requested specs and (quantities) from Landscape Architect's plans:

- 12-15' o.a. Height, single trunk (x51)

- $12-15$, o.a. Height, double trunk (x4)

- 12-15' o.a. Height, triple trunk (x2)

- Cost of Dictyosperma was determined by using the nursery's prices for similarly sized trees. Salazar's Two Sisters Nursery sells specimen-grade Dictyosperma for $\$ 20 / \mathrm{ft}$. We multiplied that number by 13.5 (median of LA's requested 12-15', specimens) to reach an approximate price per palm of $\$ 270$.

- Live Oak, Quercus virginiana

- Requested specs and (quantities) from Landscape Architect's plans:

- 35' o.a., 2-5 trunks, 8-12" caliper (x5)

- Cost of Quercus was determined by finding a similarly 
sized tree from Stewart's Tree Service in Brooksville, Florida. Here, a 32' o.a. Height, 12" caliper specimen Live Oak sells for $\$ 3,000$.

- Royal Poinciana, Delonix regia

- Requested specs and (quantities) from Landscape Architect's plans:

- 25' o.a. Height, 12" caliper (x4)

- Since no specimen Delonix grown in nurseries with the requested specifications were found, it was determined that another method of price calculation was needed. The following method was utilized in calculating the price of a specimen Royal Poinciana:

- From Purdue University's Department of Horticulture: Tree Value $=$ Base Value $\mathrm{x}$ Cross Section Area x Species Class x Condition Class $x$ Location Class, where:

- Base Value is the dollar amount assigned to one cross-section unit (square inch or square centimeter) of a tree's trunk cross-section area. To compute the base value, find the cost (usually the installed price) of a replacement-size tree from a local nursery or landscape company. Then, divide that amount by the trunk cross-sectional area of the replacement tree.

- Cross-Section Area is used to express tree size. It is the cross-sectional area of the tree trunk measured about one foot $(30 \mathrm{~cm})$ above ground level for trees with trunk size up to 12 inches $(30 \mathrm{~cm})$ in diameter, or at about $41 / 2$ feet (140 $\mathrm{cm})$ above ground level for trees with greater than 12 inch $(30 \mathrm{~cm})$ trunk diameter. Cross-section area can be calculated from trunk diameter by using the formula diameter $2 \times 0.7854$.

- Species Class is an assigned value based on all the landscape merits of a landscape tree species and its accompanying potential for problems. For the purposes of this study 1 was used for this value.

- Condition Class is a factor indicating the health, vigor and life expectancy of a tree, as well as its quality of form relative to a "perfect specimen" of that 
species. This value can be any percentage from $1 \%$ to $100 \%$, but is commonly expressed as one of five percentage categories $(100,80,60$ to 40 , $20,0)$. Since a specimen tree is requested, 100, or 1, was used for this value also.

- Location Class is based on the functional and aesthetic contribution, which the tree makes to the site, the placement of the tree on the site, and the importance of the location in the landscape context of the community. This factor can be rated at any percentage from $1 \%$ to $100 \%$. For Specimen trees, this value is $100 \%$ or 1 .

- Calculations: Base Value $=20.3$, Cross-Section Area $=113.1$, Species Class $=1$, Condition Class $=1$, Location Class $=1$

○ $20.3 * 113.1 * 1 * 1 * 1=\$ 2295.93$ for a specimen Royal Poinciana.

- Cost of Silva Cells were based upon calculations given by the provider's website, http://www.deeproot.com/products/silva-cell/cost, in conjunction with specs on Landscape Architect's plans.

○ 12 cells/tree*18,432 cu. ft./tree*4 trees* $\$ 16 /$ sq. $\mathrm{ft}=\$ 1,179,648$

- Final Calculation of Cost Comparison:

- Cost of trees 12 ' or less: $\$ 58,994$

- Cost of trees as specified by Landscape Architect: $\$ 118,696.7$

- Cost of Silva Cells: $\$ 1,179,648$

- (Cost of trees as specified by Landscape Architect) + (Cost of Silva Cells) $=1,298,344.7-($ Cost of trees 12' or less $)=\mathbf{1 , 2 3 9 , 3 5 0 . 7}=$ Cost Difference. 
Questionnaire for Assessing Adult Perception of Soundscape Park's Landscape Design

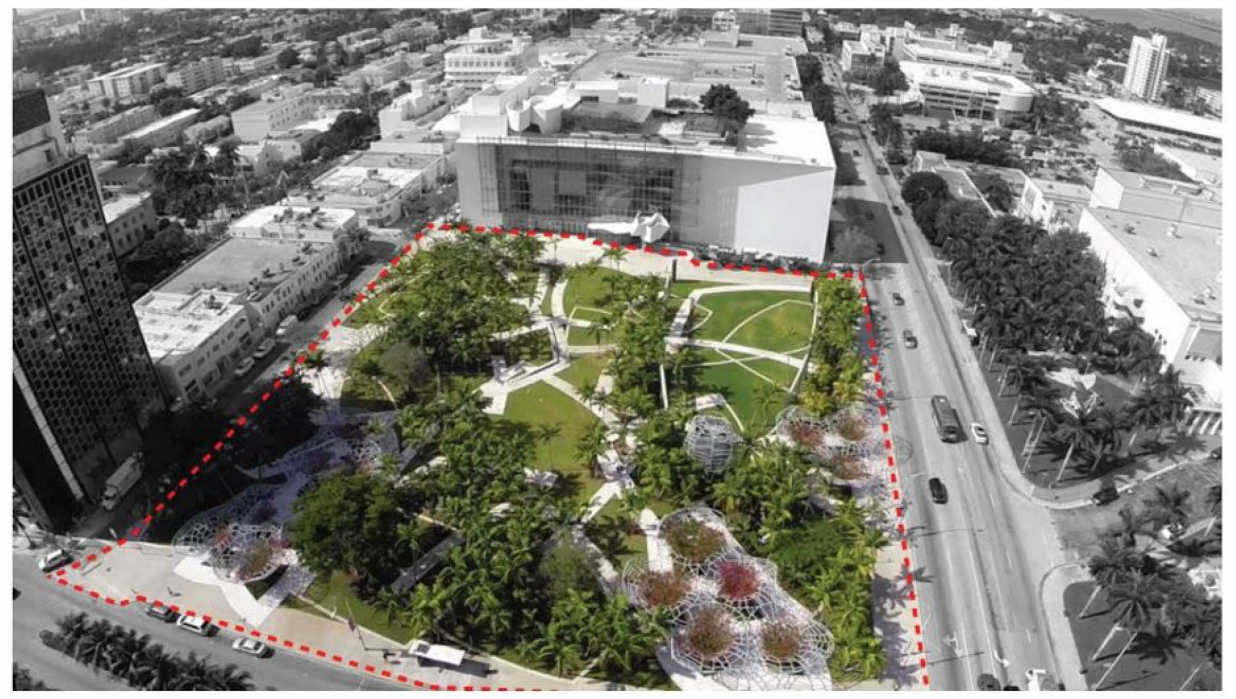

Demographic Questions

1. I am: male___ female ; do not wish to disclose this information

2. My age range is: $18-25$ 76- 85

$26-35 \ldots 36-45 \ldots$ _ _ $\quad 46-55$ ; $56-65$ 65-75

3. What is your geographic relationship to this park?
a. I live near this park
b. I work near this park
c. I live and work near this park
d. I do not live or work near this park, but come here anyway
e. I am visiting this park while on a trip from out of town
f. I am an international visitor

4. How long have you been visiting this park?
a. This is my first visit
b. Less than one year
c. One year
d. More than one year
e. More than three years
f. Since it was built in 2011

5. How often do you visit this park?
a. Very infrequently (once per year, or less)
b. Infrequently (2-3 times per year)
c. Somewhat frequently (1 time per month)
d. Frequently (1-2 times per week)
e. Very frequently (More than 3 times per week)
f. Every day 
6. What form of transportation do you usually use to get to this park? (circle all that apply)

a. Personal vehicle

b. Bicycle, Skateboard, or Roller skates

c. By foot

d. Taxi, Bus, Trolley

e. Other (Please explain)

7. Has having bike racks and a bus stop at the park encouraged you to bike here or ride the bus here?

a. Yes

b. No

c. Other (Please explain)

8. What are the reasons that you use or visit this park? (circle all that apply)

a. I walk through it to get where I am going

b. For listening to the performances of the New World Symphony

c. For Art Basel events

d. For Soundscape Cinema Series film screenings

e. For other community events and performances

f. I eat my lunch here

g. For exercising (yoga, jogging, running, biking, walking, skating, skateboarding, etc.)

h. For reading

i. For relaxing

j. To enjoy nature

k. To people watch

I. To meet people

m. Other (Please explain)

9. During your visits approximately how long do you typically stay in this park?

a. Less than 15 minutes

b. Less than 1 hour

c. 1 - 3 hours

d. More than 3 hours

e. Other (Please explain)

\section{Experiential Questions}

1. Spending time in this park positively influences my satisfaction with quality of life in this city. Agree Disagree

Strongly Disagree

2. Spending time in this park helps me to cope with the demands of work, family and other stressful situations. $\begin{array}{llll}\text { Strongly Agree } & \text { Agree } & \text { Disagree } & \text { Strongly Disagree }\end{array}$

3. The features I enjoy most in this park are (circle all that apply):

a. Overall character of the park

b. Views

c. Plants (trees, flowers)

d. Steel sculptural elements (shade structures located on entry walks)

e. Sound quality during music and movie performances

f. Fresh air, sunshine, breezes

g. Outdoor projection area

h. Lawn areas

i. Stone benches/seat walls

j. Other (Please explain)

4. Which element(s)/use(s) would you like to see added to this park? (Please fill in the blank)

5. Which elements are not necessary, if any, or detract from this park? (Please fill in the blank) 
6. Do you perceive the landscape design of this park as environmentally friendly?

a. Yes

b. No

c. I am not aware of it

d. Other (Please explain)

7. Are you aware of the air quality benefits that this park provides to the City of Miami Beach? Yes

No

8. Are you aware of the storm water benefits that this park provides to the City of Miami Beach? Yes No

9. Have you visited the park during music performances, outdoor film screenings, or other cultural events?

Yes

No

10. If yes, were you satisfied with the quality of open spaces during these events?

Yes

No

Other (Please explain)

11. If you visited the park during music performances and/or outdoor film screenings, were you satisfied with the sound quality during these events?
a. Very satisfied
b. Somewhat satisfied
c. Neither satisfied / Nor dissatisfied
d. Somewhat dissatisfied
e. Very dissatisfied
f. I have not visited the park during these events

12. If you visited the park during music performances and/or outdoor film screenings, were you satisfied with the projection quality during these events?
a. Very Satisfied
b. Somewhat satisfied
c. Neither satisfied / Nor dissatisfied
d. Somewhat dissatisfied
e. Very dissatisfied
f. I have not visited the park during these events

13. Has the existence of this park increased your exposure to music performances or other cultural events?

Yes

No

14. What else, if anything, you would like to add about your experience in, or perception of this park? (Please fill in the blank)

Thank you for your time! 